\title{
Metabotropic Glutamate Receptor 4
}

National Cancer Institute

\section{Source}

National Cancer Institute. Metabotropic Glutamate Receptor 4. NCI Thesaurus. Code C114534.

Metabotropic glutamate receptor 4 (912 aa, 102 kDa) is encoded by the human GRM4 gene. This protein plays a role in the regulation of $\mathrm{G}$ protein-dependent signaling. 